DOI: https://doi.org/10.34069/AI/2021.46.10.10

How to Cite:

Husieva, V., Oderiy, O., Petrova, I., Fomina, T., \& Vuima, A. (2021). Features of the investigation of premeditated murders committed by persons with mental disorders in the practice of Ukraine. Amazonia Investiga, 10(46), 109-117. https://doi.org/10.34069/AI/2021.46.10.10

\title{
Features of the investigation of premeditated murders committed by persons with mental disorders in the practice of Ukraine
}

\section{Особливості розслідування умисних вбивств, вчинених особами з психічними розладами за практикою України}

Received: September 20, 2021

Accepted: October 30, 2021

\begin{abstract}
The purpose of the article is to determine the procedural and tactical features of the investigation of premeditated murders committed by persons with mental disorders, taking into account the judicial and investigative practice of Ukraine. The authors use general and special methods that allow obtaining scientifically based conclusions and suggestions, such as dialectical, system-structural, generalizing, logical, statistical methods. The authors claim that $7,46 \%$ of criminal proceedings committed by persons with mental disorders and requiring the application of compulsory medical measures are sent to court annually in Ukraine. It has been established that persons with alcohol and drug addiction are more prone to premeditated murders. It is determined that the issue of application of compulsory medical measures is decided by an expert during forensic psychiatric examinations. It is proved
\end{abstract}

\author{
Written by: \\ Vlada Husieva ${ }^{30}$ \\ https://orcid.org/0000-0001-8614-1573 \\ Oleksiy Oderiy ${ }^{31}$ \\ https://orcid.org/0000-0002-6999-4387 \\ Iryna Petrova ${ }^{32}$ \\ https://orcid.org/0000-0002-1652-6715 \\ Tetiana Fomina ${ }^{33}$ \\ https://orcid.org/0000-0002-9513-1673 \\ Anastasiia Vuima ${ }^{34}$ \\ https://orcid.org/0000-0002-6215-5361
}

\footnotetext{
${ }^{30}$ Professor of the Department of Criminalistics, Forensic Science and Pre-medical care of Kharkiv National University of Internal Affairs, Dc Sc in Law, Associate Professor, Kharkiv, Ukraine.

${ }^{31}$ Professor of the Department of Criminal Law Subjects and Forensic Examinations, Faculty No. 1, Donetsk Law Institute of Ministry of Internal Affairs of Ukraine, Dc Sc in Law, Associate Professor, Kryvyi Rih, Ukraine.

${ }^{32}$ Principal Researcher of the Laboratory of Theoretical Studies, Editorial and Publishing and Scientific and Methodological Activities, Hon. Prof. M. S. Bokarius Kharkiv Research Institute of Forensic Examinations, Dc Sc in Law, Professor, Honored Lawyer of Ukraine, Kharkiv, Ukraine.

${ }^{33}$ Professor of the Department Criminal Process and Organization of Pre-trial Investigation of Kharkiv National University of Internal Affairs, Dc Sc in Law, Associate Professor, Kharkiv, Ukraine.

${ }^{34}$ Adjunct of the Department of the Organization Educational and Scientific Training of Kharkiv National University of Internal Affairs, Kharkiv, Ukraine.
} 
that the current criminal procedure legislation of Ukraine, although it determines the grounds for the appointment of examinations of this type, but investigators appoint them in $79 \%$ of criminal proceedings, even in the absence of statutory grounds. It is established that the appropriateness of conducting investigative (search) actions with the participation of a person with mental disorders is determined by the investigator or prosecutor on the basis of an expert opinion.

Keywords: premeditated murders, investigation, mental disorders, insanity, forensic psychiatric examination.

\section{Introduction}

The investigation of premeditated murders is a rather complex activity, as investigators are tasked with establishing the identity of the murderer, identification the existence of components of crime in his actions and collecting evidence of the latter's guilt. Establishing the identity of the offender is one of the highest priorities in this activity, because this element is associated with others, including: method, tools and means, motives and purpose of the act, and so on.

According to statistics compiled by the General Prosecutor's Office of Ukraine, 908 criminal proceedings were filed in court on charges of premeditated murder in 2017, 858 in 2018, 834 in 2019, and 864 in 2020. In this case, petitions for the application of coercive measures of a medical nature in 2017 were sent to court - 68, in 2018 - 74, in 2019 - 67, in 2020 - 65 (Office of the Prosecutor General of Ukraine, 2021). That is, on average annually among criminal proceedings for intended killing, which were sent to court, $7.46 \%$ of them were sent with a request to apply coercive medical measures. This shows that the proportion of people who have lost the lives of others, being in a state of insanity and in need of treatment is quite significant.

The complexity of the issue of criminal liability of persons with mental disorders who have committed premeditated murder is due to many factors. These include procedural and tactical requirements that investigators should follow in their work during the investigation. These factors що до вчинення умисних вбивств більш схильні особи, які мають синдром залежності від алкоголю та наркотичних засобів. Визначено, що питання про застосування примусових заходів медичного характеру вирішується експертом при проведенні судовопсихіатричних експертиз. Доведено, що чинне кримінальне процесуальне законодавство України хоча й визначає підстави для призначення експертиз зазначеного виду, однак слідчі призначають їх у 79\% кримінальних проваджень, навіть за відсутності визначених законом підстав. Установлено, що доцільність проведення слідчих (розшукових) дій за участю особи, яка має психічні розлади визначається слідчим або прокурором на підставі висновку експерта за результатами проведення судовопсихіатричної експертизи.

Ключові слова: умисне вбивство, розслідування, психічні розлади, неосудність, судово-психіатрична експертиза.

also include those related to the identity of the offender and due to the presence of mental disorders that affect his behavior. For example, due to mental disorders, some people may accuse themselves of committing a crime, especially if it is committed by a group of people. This conclusion was made by M.C. Mogavero in his study, noting that the probability of falsely confession was higher among juveniles, those with mental illness and intellectual disabilities, and cases with multiple suspects (Mogavero, 2020, p. 299). Investigators should also take into account the fact that persons suspected of premeditated murders try to imitate a mental disorder or mental illness, hoping that the court will find them insane and this will allow them to avoid criminal liability. Similar cases occur not only in the investigative and judicial practice of Ukraine, but also in other countries. Thus, in the United States, a jury can rule in the case of "Not Guilty by Reason of Insanity (NGRI)". In some countries the presence of mental disorders is generally considered as a mitigating circumstance.

Thus, during the investigation of premeditated murders committed by persons with mental disorders, in addition to performing the general tasks of criminal proceedings, investigators must solve a number of tactical tasks. The purpose of this study is to determine the procedural and tactical features of the investigation of premeditated murders committed by persons with mental disorders, taking into account the judicial and investigative practice of Ukraine. To 


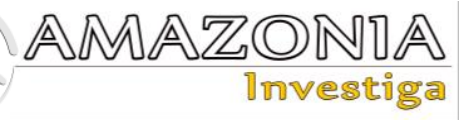

achieve this goal, the following tasks are set: 1) to study the main legal acts of Ukraine and international legal acts governing the investigation of crimes, including premeditated murders committed by persons with mental disorders; 2) to determine the peculiarities of the appointment of forensic psychiatric examinations and tactics of conducting certain investigative (search) actions with the participation of persons who have mental disorders and are involved in the commission of premeditated murders.

\section{Literature Review}

A large number of works by criminologists and forensic scientists are devoted to the study of the identity of the offender in criminal proceedings on murders. Most scientists state the fact that people with a high level of legal culture and legal awareness, a high standard of living and who are endowed with value orientations are less prone to commit crimes of this kind. In contrast, there are individuals who commit criminal offenses more often than others. In particular, the latter include mentally ill and emotionally unstable offenders, who make up a significant proportion of those whose criminal behavior has drawn them into the criminal justice system, including a subgroup tried and convicted of premeditated murder (Miley, Heiss-Moses, Cochran, Heide, Fogel, Smith \& Bejerregaard, 2020, p. 381).

Thus, in their study, H. Hachtel, M. Nixon, D. Bennett, P. Mullen, J. Ogloff found that of the 435 offenders (convicted between 1997 and 2005, in Victoria, Australia) in 43 (9.9\%) were diagnosed with a mental illness. Murderers with mental disorders were 3,19 times more motivated by revenge than offenders who did not have disorders and those who were not diagnosed. The researchers also found that the social danger of the latter is that they are much more likely to kill family members and other people they know (Hachtel, Nixon, Bennett, Mullen \& Ogloff, 2021, p. 3168).

B.F. Hummadi, F.A. Al-Kadhimi, G.A. Al-Mashhadani have investigated the materials of 70 cases initiated in connection with the killings in Iraq. According to the study, researchers found that about $38,6 \%$ of killers did not have mental illness, $17.1 \%$ had personality disorders, $32.9 \%$ had mental disorders and $8.6 \%$ - neurotic disorders (Hummadi, Al-Kadhimi \& Al-Mashhadani, 2020, p. 462).

Psychotic symptoms during life were noted among $11 \%$ of US offenders, which is consistent with previous reports, including $18 \%$ of mass murderers who did not use firearms, and $8 \%$ of those who used them (Brucato et al, 2021).

M. Bouthier and V. Mahé found that of the 79 French citizens who suffered from paranoia, which is a mental disorder and were convicted of crimes, 30 persons committed murder and attempted murder (Bouthier, \& Mahé, 2019, p. 162).

A separate group in the context of our study consists of persons who have committed premeditated murders and have a syndrome of dependence on alcohol, drugs or psychotropic substances. This is due to the fact that the use of these substances and means weakens or generally paralyzes the inhibitory processes, due to which addicts develop personality and behavioral disorders. In particular, L. Eriksson, S. Bryant, S. McPhedran, P. Mazerolle, R. Wortley have received a triumphant conclusion after testing 302 people convicted of murder in Australia. The researchers found that $38,8 \%$ of people had a high level of alcohol problems and 30,8\% had a drug problem. At the same time, a large proportion of murderers abused these substances in the year preceding the crime (Eriksson, Bryant, McPhedran, Mazerolle \& Wortley, 2021, p. 618).

To summarize, it should be noted that the research of many foreign scientists is devoted to establishing the relationship between a person's mental disorders and his tendency to commit certain types of crimes, including various types of murder. These data confirm the fact that people with mental illness and behavioral disorders are more likely to commit crimes. This highlights the issue of criminal liability of persons with mental disorders, which is difficult for criminal justice, psychiatry and society (Valença, Carvalho de Oliveira, Telles, da Silva, da Silva, Barros \& Nardi, 2021).

The solution of this issue is also relevant for Ukraine.

\section{Methodology}

The purpose of the article is to determine the procedural and tactical features of the investigation of premeditated murders committed by persons with mental disorders, taking into account the judicial and investigative practice of Ukraine.

The study used a set of general and special methods, which was the key to achieving this 
goal. In particular, the systems approach determines the application of these methods and allows studying the problems. The dialectical method allows establishing the purposes of research in dynamics and interrelation, to find out tactical and procedural features of investigation of premeditated murders committed by the persons who could not realize value of the actions and to control them, and also the persons having mental disorders. The method of systematic analysis of legal provisions allows identifying key trends in the application of legislation in the investigation of premeditated murders committed by persons with mental disorders, to identify gaps and traditions in legal norms and to formulate proposals for improving criminal procedure legislation in Ukraine. The method of generalization allows to form proposals for improving the current legislation, in particular, the grounds for mandatory appointment of forensic psychiatric examinations in criminal proceedings, expanding the grounds for prescribing forensic psychiatric examinations and the introduction of the Unified Register of Persons with Mental Disorders. The logical method is the basis for distinguishing the procedural and tactical features of the investigation of premeditated murders committed by a person with mental disorders. Statistical methods (grouping, analysis of quantitative indicators) were used to summarize and process statistical reports, materials of investigative and judicial practice of Ukraine.

\section{Results and Discussion}

The presence of mental disorders in a person to some extent determines a person's behavior, and sometimes deprives him of the ability to realize and control their actions. In the context of our study, a distinction should be made between "the person of a criminal with mental disorders" and "an insane person who has committed a socially dangerous act", because the correct understanding of the definitions of these concepts depends on the form and procedure of criminal proceedings. Therefore, first of all, we propose to determine what should be understood by these concepts and to determine the tactical and procedural features of criminal proceedings against these categories of persons in Ukraine.

According to the Criminal Code of Ukraine, a person who at the time of committing a socially dangerous act could not be aware of his actions (inaction) or control them due to chronic mental illness, temporary mental disorder, dementia or other mental illness, in connection with which is not subject to criminal liability. Coercive medical measures may be applied to such a person by a court decision (Law of Ukraine No. 2341-III, 2001).

Compulsory treatment of mentally ill offenders is provided by both the national legislation of Ukraine and international legal acts. According to the Standard Minimum Rules for the Treatment of Prisoners adopted by the First United Nations Congress on the Prevention of Crime and the Treatment of Offenders (Geneva, 30 August 1955), persons recognized as mentally ill should not be subjected to imprisonment, and therefore it is necessary to take measures to transfer them to mental institutions as soon as possible. Prisoners suffering from other mental illnesses or disabilities should be supervised and treated in special facilities under the guidance of doctors (United Nations Congress on the Prevention of Crime and the Treatment of Offenders, 1955). The Principles for the Protection of Mentally Ill Persons, approved by the UN General Assembly on 17 December 1991 (Office of the high commissioner for Human Rights, 1991), provide that persons who have committed acts prohibited by criminal law and detained during a trial or investigation if they are presumed or found to be suffering from a mental illness, the general principles of protection shall be applied in full with such minimum changes and exceptions as are necessary in the circumstances, which shall not prejudice their rights. Provisions of domestic law may authorize a court or other competent authority to decide, on the basis of an independent medical opinion, to place such persons in psychiatric institutions for isolation for the purpose of providing psychiatric care (MI Principles, 1991).

The application of coercive medical measures is considered one of the most difficult and complex, due primarily to the versatility of this institution - it is at the intersection of legal, sociological and medical fields of knowledge (Bersh, 2017, p. 4). The main purpose of the application of coercive medical measures is to ensure the maintenance of public safety and order by protecting society from dangerous encroachments on persons with mental disorders. Coercive measures of a medical nature should be applied only if there is a reasoned opinion of psychiatric experts that the person suffers from a mental illness or other mental disorder, which causes his insanity or limited sanity and necessitates the application of such measures (Resolution of the Plenum of the Supreme Court of Ukraine, No. 7, 2005).

Establishing the necessity to apply coercive medical measures to a person is the basis for 


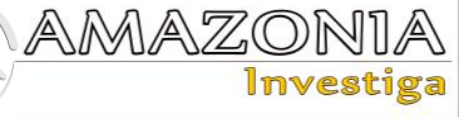

changing the procedure for conducting a pre-trial investigation. The decision of this question occurs during carrying out forensic psychiatric examination. This examination is appointed after the person has acquired the status of a suspect and in the case of information that raises doubts about the sanity, limited sanity of the person. Such information includes:

1) the presence in accordance with a medical document of a person with a mental disorder or mental illness;

2) the behavior of a person during or after the commission of a socially dangerous act was or is inadequate (obscuration of consciousness, violation of perception, thinking, will, emotions, intellect or memory, etc.) (Law of Ukraine No. 4651VI, 2012).

The procedure of criminal proceedings on the application of coercive medical measures is regulated by Chapter 39 of the CPC of Ukraine and provides for clarification of special circumstances to be established, mandatory participation of defense counsel, special precautionary measures and a separate procedure for pre-trial investigation (Law of Ukraine No. 4651-VI, 2012). The grounds for criminal proceedings for the application of coercive medical measures, provided by the law of Ukraine on criminal liability, are the existence of sufficient circumstances to believe that:

1) the person has committed a socially dangerous act provided by the law of Ukraine on criminal liability, in a state of insanity;

2) the person committed a criminal offense in a state of sanity, but fell ill with a mental illness before the verdict (Law of Ukraine No. 4651-VI, 2012).

Therefore, if at the time of the murder a person could not realize the significance of his actions and control them, and such a person requires the application of coercive medical measures, criminal proceedings against him are carried out in a special manner.

Regarding the definition of the term "person of a criminal with mental disorders", scientists define it differently. Yu. Antonyan, and S. Borodin understand it as a person who has mental disorders that have not reached the psychotic level and do not exclude sanity, but entail personal changes and can lead to deviations in behavior. Such anomalies complicate the social adaptation of such a person and reduce his ability to control their actions (Antonyan \& Borodin, 1998 , p. 8). That is, under this concept the latter understand a person who, although he has mental disorders, but at the time of the crime was aware of the importance of their actions and could control them.

It should be noted that despite the fact that in Ukraine there is a presumption of mental health, according to which any person who commits an illegal act is considered able to be aware of their actions and manage them in full, unless proven otherwise (Law of Ukraine No. 1489-III, 2000), the presence a person with a mental disorder is the basis for the appointment of a forensic psychiatric examination. Moreover, the criminal procedure law stipulates that in the case of information that raises doubts about the sanity or limited sanity of a person in order to determine his mental condition, the investigator or the prosecutor is obliged to appoint an examination. Such information includes:

1) the presence in accordance with a medical document of a person with a mental disorder or mental illness;

2) the behavior of a person during or after the commission of a socially dangerous act was or is inadequate (obscuration of consciousness, violation of perception, thinking, will, emotions, intellect or memory, etc.) (Law of Ukraine No. 4651VI, 2012).

During a psychiatric examination of a murder suspect reveals the following: there is reason to believe that the person has a mental illness; there are signs of existing mental disorders; type of mental illness; whether the mental state of the patient allows to carry out with it investigative (search) actions; whether the suspect is a chronic alcoholic or drug addict and needs treatment. Some mental signs of the suspect can also be established, which indicate the following: he was treated in a psychiatric hospital; susceptibility to sexual violence in extreme conditions; predisposition to sadism and torture of the victim; whether prone to inflicting other physical suffering on the victim, etc. (Panov, Shepitko \& Konovalova, 2011, pp. 173-175).

In order to unambiguously understand these grounds, we propose to analyze them in detail. Examining the first ground, which is that a person has a mental disorder or mental illness, according to a medical document, it should be noted that in Ukraine there is no single register of mentally ill patients, which complicates the process of verifying and obtaining data registered 
with a psychiatrist. Because of this, investigators during the investigation should send several inquiries to various institutions, enterprises to obtain information about the presence of a mental disorder or mental illness. In practice, there are cases when a person was not registered with a psychiatrist, but was discharged from military service due to a mental illness. Thus, in our opinion, formal inquiries to medical institutions at the place of registration or residence of a person may indicate the incompleteness of the investigation, which violates the requirements for the content and form of criminal proceedings regarding completeness, objectivity, etc.

In order to simplify the process of determining the presence of mental disorders or mental illnesses in a person, we have analyzed the regulations of the Ministry of Health and identified a list of those that may contain information that casts doubt on the sanity of the person. These include: control card of dispensary supervision of a patient with mental disorders and a person who has mental disorders due to the use of psychoactive substances, statistical coupon for a patient removed from the dispensary supervision of a psychoneurological / narcological institution, statistical card of a patient who was eliminated of psychiatric (narcological) inpatient, act of inpatient, outpatient, correspondence, posthumous forensic psychiatric examination, act of psychiatric examination of the convict, register of inpatient and outpatient forensic psychiatric examination, Protocol of mandatory preliminary and periodic psychiatric examinations, personal examination, psychiatric examination treatment, medical certificate of mandatory preliminary and periodic psychiatric examinations (Regulatory documents of the Ministry of Health of Ukraine, 2021).

Special attention needs to be paid to the documents on the suspect's treatment in connection with the suspect's head injuries, brain contusions, etc., as well as spinal injuries, spinal cord injuries, which are now actively emphasized by scientists in their studies (Aaronson, Bordelon, Brakel \& Morrison, 2021, p. 60; Gus'kova, 1995, p. 116). This is due to the fact that such injuries in the future can provoke changes in anatomical and physiological processes in the human body and lead to mental disorders or mental illness. We believe that such facts should also serve as a basis for the appointment of a forensic psychiatric examination of the suspect in the murder.

With regard to the second ground, it was also emphasized by the Supreme Court of Ukraine in the decision of the Plenum of 30 May 1997 № 8 "On forensic examination in criminal and civil cases", explaining that forensic psychiatric examination must be appointed in respect of a person due to his mental defects is unable to correctly perceive the circumstances relevant to the case, and to testify about them (paragraph 3, paragraph 14) (Resolution of the Plenum of the Supreme Court of Ukraine, No. 8, 1997).

Doubts about the mental adequacy of the person who committed the premeditated murder may arise almost immediately after the first investigative (search) action - inspection of the scene and the corpse. In particular, they can be evidenced by the manner of causing the death, the chaotic nature of the bodily injuries, their numerous number, actions that indicate mockery of the corpse, the situation at the scene, and so on. However, in this case, the identity of the offender should definitely be investigated.

To determine the adequacy of a person's behavior, the investigator, during certain investigative (search) actions should pay attention to certain signs of mental disorders, including: 1) emotional background disorders (sudden mood swings): anxiety, fear, irritability, anger, tearfulness, isolation, atypical joy; 2) disorders of memory, attention, are expressed in inconsistency of expression, constant distraction from the main topic, distraction, fatigue, inability to remember well-known words (names of objects), to reproduce recent events, silence in the middle of the phrase, "looping" on one thought; 3) demonstrative, theatrical behavior, such as suicide attempts, grimaces, which are most often found in hysterical psychopaths; 4) impaired coordination of movements, trembling hands - possible forms of mental disorders in alcoholism, reactive states, vascular diseases; 5) sweating, cyanosis of the skin (mainly palms) - characteristic of people who have suffered brain injuries, suffer from alcoholism, schizophrenia; 6) diffuse gaze as a consequence of craniocerebral and other diseases (Radaev, 1987, p. 66).

It should be noted that the establishment of the presence of mental disorders in a person may occur after the commission of premeditated murder. An example is a criminal case in which a woman who has not previously been diagnosed with any mental disorder or mental illness murdered and has been diagnosed with a chronic mental illness during a forensic psychiatric examination. During the investigation of the criminal proceedings, investigators found that the mother had inflicted multiple penetrating stab 


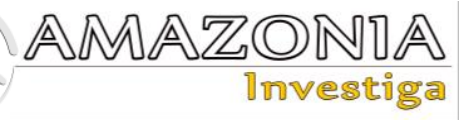

wounds to the head and torso, with internal injuries, to her 13-year-old daughter, which led to the development of blood loss, which led to her death. Later, the latter, acting with special cruelty, separated the victim's head from the body, and putting it in a plastic bag, leaving the crime scene, walked $6 \mathrm{~km}$ naked, after which she was stopped by police (Case no 619/4110/20, 2020). Prior to the incident, the woman never sought help from a psychiatrist, and during a forensic psychiatric examination, the latter was diagnosed with a chronic mental illness in the form of paranoid schizophrenia, which led the court to decide on the need for coercive medical measures.

In order to solve the issue of the peculiarities of the appointment of forensic psychiatric examination, we conducted an analysis of investigative and judicial practice. As a result, it was found that investigators in criminal proceedings for murder almost always order a forensic psychiatric examination, even in the absence of statutory grounds. In particular, we found that in $79 \%$ of cases (out of 100 analyzed criminal proceedings) forensic psychiatric examinations were appointed by investigators, in the absence of grounds for their appointment, in $19 \%$ of proceedings psychiatric examinations were not appointed at all, in $2 \%$ of criminal proceedings type was mandatory (two persons were registered with a psychiatrist due to mental disorders)

In the future, we conducted a survey of police investigation departments, in order to establish the facts that became the basis for the appointment of forensic psychiatric examinations. It was established that the most common circumstance that became the basis for the decision to appoint a forensic psychiatric examination, investigators called the lack of a logical motive for the murder. Investigators also explained that committing premeditated murder is an act of violence associated with inflicting special torment and suffering on a person, which, except for the threat to one's own life, a completely mentally healthy person is not capable of.

According to the results of our analysis of the conclusions of forensic psychiatric experts, in these criminal proceedings, it was found that $14 \%$ of people had mental and behavioral disorders due to alcohol, drugs (opioid, amphetamine, etc.), $8 \%$ of the accused were in intoxicated, $4 \%$ had alcohol dependence (chronic alcoholism), $2 \%$ had an emotionally unstable personality disorder, $2 \%$ had a mental illness, $1 \%$ of defendants had a personality and behavioral disorder due to organic brain damage, and $1 \%$ clinical signs of post-traumatic stress disorder. These data suggest that although a person has not been diagnosed with a mental disorder or mental illness, this does not preclude them from having certain mental health problems that need treatment.

Such conclusions have been confirmed by other studies conducted by our compatriots. Ukrainian scientists V. Ortynsky and L. Hula during the study of investigative and expert activities in some regions of Ukraine (Lviv, Rivne, Ternopil regions) found that the investigation of the murders of $80 \%$ of suspects revealed mental disorders, in particular: psychopathy - 35\%, schizophrenia $-20 \%$, dementia - $12 \%$, the effects of organic diseases of the central nervous system - 5\%, chronic alcoholism - 7\%, epilepsy - 2\% (Ortynsky \& Hula, 2019, p. 6).

The investigation of premeditated murders committed by persons with mental disorders is also characterized by certain features. In particular, criminal procedure law guarantees the mandatory involvement of a lawyer for such persons. If such a person is declared incompetent or partially incompetent, in addition to the defense counsel, a legal representative shall also be involved in the proceedings together with him / her. The further course of the investigation depends on the results of the forensic psychiatric examination, which is mandatory for the appointment. If the forensic expert does not indicate the need to apply coercive measures of a medical nature, the investigation will be carried out in the general order.

As for the tactics of conducting certain investigative (search) actions, any restrictions on their conduct are not directly provided by the criminal procedure legislation. At the same time, the possibility of their holding is determined by the investigator, the prosecutor on the basis of the conclusion of the forensic psychiatric examination. At the same time, according to Part 2 of Art. 506 of the CPC of Ukraine, if the nature of the mental disorder or mental illness of a person prevents procedural actions with his participation in a court hearing, the prosecutor, the court have the right to decide on appropriate procedural actions without such person (Law of Ukraine No. 4651-VI, 2012). In addition, the presence of mental disorders in a person excludes the possibility of conducting psychophysiological examination using a polygraph (Aleksieiev \& Aleksieieva-Protsiuk, 2018, p. 104), and the possibility of prescribing 
forensic psychological examination using a polygraph.

\section{Conclusion}

In conclusion, it should be noted that the procedure for investigating premeditated murders committed by a person with mental disorders in Ukraine is determined on the basis of an expert opinion based on the results of a forensic psychiatric examination. If it is necessary to apply coercive measures of a medical nature against a person, this criminal proceeding will be carried out in a special manner.

The presence of a person suspected of committing premeditated murder, mental disorders that do not exclude the sanity of the latter, to some extent determine a number of procedural features that affect the course of the investigation.

The appointment of a forensic psychiatric examination of persons with mental disorders is mandatory in Ukraine. The question of the possibility of conducting investigative (search) actions with their participation should be decided by an expert during the said examination. In Ukraine, it is forbidden to use a polygraph to people with mental disorders.

The analysis of the current criminal procedural legislation of Ukraine, investigative-judicial practice and research of scientists allowed formulating a number of provisions that need further research and implementation in order to improve the investigation of premeditated murders committed by persons with mental disorders. Including:

1) expansion of the grounds for forensic psychiatric examinations in criminal proceedings, namely: supplementing them with grounds for the need for forensic psychiatric examinations in case of suspects head and spine injuries, brain contusions, spinal cord injuries, as well as in case of serious and especially serious crime by a person who was in a state of alcohol or drug intoxication;

2) introduction of the functioning of the Unified Register of Persons with Mental Disorders in Ukraine;

3) addition of Part 2 of Art. 242 of the CPC of Ukraine by the need to appoint an expert examination of a murder suspect in order to determine his mental state.

\section{Bibliographic references}

Aaronson, A.L., Bordelon, S.D., Brakel, S.J., \& Morrison, H. (2021). A review of the role of chronic traumatic encephalopathy in criminal court. Journal of the American Academy of Psychiatry and the Law, 49(1), 60-65.

Aleksieiev, O. O., \& Aleksieieva-Protsiuk, D. O. (2018). Legal Conditions for Conducting of Psychophysiological Research Using a Polygraph in Criminal Proceedings. Scientific Herald of the National Academy of Internal Affairs, 1(106), 96-109.

Antonyan, Yu.M., \& Borodin, S.V. (1998). Criminal behavior and mental abnormalities. Moscow: Spark, 215 p. Recovered from http://lawlibrary.ru/izdanie491.html.

Bersh, A.Y. (2017). Compulsory measures of medical character: legal nature and types. (Candidates of juridical sciences' thesis in specialty) Criminal Law and Criminology; Criminal-Executive Law». National University «Odessa Law Academy», Odessa, 188 p.

Bouthier, M., \& Mahé, V. (2019). Paranoid personality disorder and criminal offense. Encephale, 45(2), 162-168.

Brucato, G., Appelbaum, P.S., Hesson, H., Shea, E.A., Dishy, G., Lee, K., Pia, T., Syed, F., Villalobos, A., Wall, M.M., Lieberman, J.A., \& Girgis, R.R. (2021). Psychotic symptoms in mass shootings v. mass murders not involving firearms: findings from the Columbia mass murder database. Cambridge University Press. Retrieved from https://www.cambridge.org/core/journals/psyc hological-medicine/article/abs/psychoticsymptoms-in-mass-shootings-v-mass-murdersnot-involving-firearms-findings-from-thecolumbia-mass-murderdatabase/50514607ADF1AC2ECEB43369B61 53E34.

Case no 619/4110/20 (Unified register of court decisions of Ukraine, September 23, 2020). Retrieved September 29, 2021, from https://reyestr.court.gov.ua/Review/91793322.

Eriksson, L., Bryant, S., McPhedran, S., Mazerolle, P., \& Wortley, R. (2021). Alcohol and drug problems among Australian homicide offenders. Addiction, 116(3), 618-631.

Gus'kova, A. G. (1995). Theoretic and practical aspects of establishing data on the identity of the accused in criminal proceedings. Orenburg: Publishing house of the Orenburg Agricultural Academy. 116 p.

Hachtel, H., Nixon, M., Bennett, D., Mullen, P., \& Ogloff, J (2021). Motives, Offending Behavior, and Gender Differences in Murder Perpetrators With or Without Psychosis. Journal of Interpersonal Violence, 36(7-8), 3168-3190.

Hummadi, B.F., Al-Kadhimi, F.A., \& Al-Mashhadani, G.A. (2020). Criminal responsibility among murderer presented to 


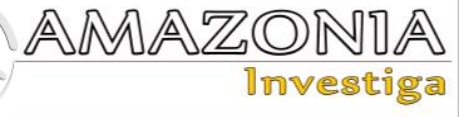

forensic committee in Al-Rashad training hospital/ forensic department. Indian Journal of Forensic Medicine and Toxicology, 14(1), 462-468

Law of Ukraine No. 1489-III. On psychiatric care (2000). Official Web site of the Verkhovna Rada of Ukraine, December 20, 2018. Retrieved from

https://zakon.rada.gov.ua/laws/show/148914\#Text.

Law of Ukraine No. 2341-III. Criminal Codes of Ukraine. Official Web site of the Verkhovna Rada of Ukraine, October 04, 2021. Retrieved from

https://zakon.rada.gov.ua/laws/show/2341-14.

Law of Ukraine No. 4651-VI. Criminal Procedure Codes of Ukraine (2012). Web site of the Verkhovna Rada of Ukraine, October 04, 2021. Retrieved from https://zakon.rada.gov.ua/laws/show/4651.

Miley, L.N., Heiss-Moses, E., Cochran, J.K., Heide, K.M., Fogel, S.J., Smith, M.D., \& Bejerregaard, B.J. (2020). An examination of the effects of mental disorders as mitigating factors on capital sentencing outcomes. Behavioral Sciences and the Law, 38(4), pages 381-405.

Misakov, V., Tsurova, L., Yandarbayeva, L., Tkhamadokova, I., \& Gapurovna, G. (2019). Certification of a regional economic complex as a highly effective tool for analysis and diagnostics of its development. Amazonia Investiga, 8(20), 451-458. Retrieved from https://amazoniainvestiga.info/index.php/amaz onia/article/view/174

Mogavero, M.C. (2020). An exploratory examination of intellectual disability and mental illness associated with alleged false confessions. Behavioral Sciences and the Law, 38(4), 299-316.

Office of the Prosecutor General of Ukraine (2021). Statistics of the Ukraine General Prosecutor Office. (n.d.).

Office of the high commissioner for Human Rights (1991). Principles for the Protection of Persons with Mental Illness and the Improvement of Mental Health Care (MI Principles). UN General Assembly Resolution 46/119 of 17 December 1991. Retrieved from https://www.equalrightstrust.org/content/unprinciples-protection-persons-mental-illnessand-improvement-mental-health-care.
Ortynsky, V.L., \& Hula, L.F. (2019). The article deals with the concept and content of forensic psychiatric examination of the suspect in the assassination attempt. Academic Journals and Conferences 6(911). Retrieved from http://science.lpnu.ua/law/all-volumes-andissues/volume-6-number-911-21-2019/articledeals-concept-and-content-forensic.

Panov, M. I., Shepitko, V. Yu., \& Konovalova, V. O. (2011). Investigator's hand book. Kyiv: In. Yure, 736 p.

Radaev, V. V. (1987). Investigation of crimes committed by persons with mental disabilities: training manual. Volgograd: High School of the Ministry of Internal Affairs of the USSR, $68 \mathrm{p}$.

Regulatory documents of the Ministry of Health of Ukraine. (2021). Forms of medical documents. Retrieved September 28, 2021, from http://mozdocs.kiev.ua/index.php?nav=8.

Resolution of the Plenum of the Supreme Court of Ukraine No. 7. On the practice of application by courts of coercive measures of a medical nature and compulsory treatment. Official Web site of the Verkhovna Rada of Ukraine, June 03, 2005. Retrieved

from https://zakon.rada.gov.ua/laws/show/v0007700 $-05 \#$ Text.

Resolution of the Plenum of the Supreme Court of Ukraine No. 8. On forensic examination in criminal and civil cases. Official Web site of the Verkhovna Rada of Ukraine, 1997. Retrieved from

https://zakon.rada.gov.ua/laws/show/v0008700 -97\#Text.

United Nations Congress on the Prevention of Crime and the Treatment of Offenders (1955). Standard Minimum Rules for the Treatment of Prisoners (on 30 August 1955: approve. Economic and Social Council at 994 th plenary meeting, on 31 July 1957). Retrieved from http//base.garant.ru/1305346/.

Valença, A.M. Carvalho de Oliveira, G., Telles, L.E.D.B., da Silva, A.G., da Silva, J.A.R., Barros, A.J.S., \& Nardi, A.E. (2021). Matricide, parricide, and filicide: Are major mental disorders or personality disorders involved? Assessment of criminal responsibility in Brazilian cases. Journal of Forensis Sciences, 66(5), 2048-2053. Retrieved from https://onlinelibrary.wiley.com/doi/10.1111/15 56-4029.14745. 